\title{
Spina bifida, diplomyelia and multiple malformations in a Texel lamb
}

\author{
Brenda Oliveira Silveira, ${ }^{12^{*}}$ (D) Marianna Bertolini2 ${ }^{\text {(D) }}$ Emília Juchem Sulzbach ${ }^{1}$ (D) \\ Maria Fernanda Wentz ${ }^{2}$ (D) Felipe Auatt Batista de Sousa ${ }^{2}$ (D) Paula Augusto Taunde ${ }^{2}$ \\ Matheus Viezzer Bianchi ${ }^{2}$ (D) Beatriz Riet-Correa ${ }^{1}$ (D) Luciana Sonne ${ }^{2}$ iD
}

${ }^{1}$ Núcleo Ruminação, Faculdade de Veterinária, Universidade Federal do Rio Grande do Sul (UFRGS), 90540-000, Porto Alegre, RS, Brasil.
E-mail: brendasilveira.vet@live.com. *Corresponding author.
${ }^{2}$ Setor de Patologia Veterinária, Faculdade de Veterinária (SPV), Universidade Federal do Rio Grande do Sul (UFRGS), Porto Alegre, RS, Brasil.

ABSTRACT: This report described the clinical and pathological aspects of open spina bifida and diplomyelia along with multiple congenital malformations in a Texel lamb. Clinically, paresis of the thoracic limbs, paralysis of the pelvic limbs and a cutaneous opening in the lumbosacral region were observed. At necropsy, there was a focally extensive disruption of the skin associated with an absence of the dorsal portions of the lumbosacral vertebrae. Additionally, diplomyelia of the lumbar segment, mild hydromyelia of thoracic segment, and moderate communicating hydrocephalus of the lateral and third ventricles were noted. Possible viral etiologies (bovine viral diarrhea virus, bluetongue virus, and Schmallemberg virus) were not detected by RT-PCR, and toxic plants were not identified. Therefore, a possible genetic cause may not be discarded.

Key words: sheep, central nervous system, neurological disorders, neuropathology.

Espinha bífida, diplomielia e múltiplas malformações em um cordeiro Texel

RESUMO: Este trabalho descreve os aspectos clínicos e patológicos de um caso de espinha bifida aberta e diplomielia, além de múltiplas malformações, em um cordeiro Texel. Clinicamente, este apresentava paresia de membros torácicos, paralisia dos membros pélvicos e uma abertura cutânea na região lombossacral desde o nascimento. À necropsia, visualizou-se solução de continuidade na pele e ausência das porções dorsais das vértebras lombossacrais. Além disso, observou-se diplomielia em segmento lombar, hidromielia discreta de segmento torácico e hidrocefalia comunicante moderada de ventrículos laterais e terceiro ventrículo. Possíveis etiologias virais (vírus da diarreia viral bovina, virus da língua azul e Schmallemberg virus) não foram detectadas através de RT-PCR, e possíveis plantas tóxicas não foram identificadas. Portanto, uma causa genética não pode ser descartada.

Palavras-chave: ovino; sistema nervoso central; distúrbio neurológico; neuropatologia.

Spina bifida is a congenital defect characterized by the absence of a dorsal portion of the vertebrae as a consequence of closure failure of the neural tube, which may result in meningocele or meningomyelocele, and it is usually accompanied by amyelia, hydromyelia, and dysraphism (POTTER et al., 2010; CANTILE \& YOUSSEF, 2016). Such defects have no sex predisposal and are commonly detected in the lumbosacral region (POTTER et al., 2010; STEELE et al., 2019). Malformations of this nature are mainly related to hereditary, nutritional, viral, and/or environmental factors (HUT et al., 2017). Intrauterine infections caused by Schmallenberg virus (SV), Bluetongue virus (BTV), and Bovine viral diarrhea virus (BVDV) are some examples (CANTILE \& YOUSSEF, 2016).
Spina bifida may be classified as open, cystic, or occult. In cases of open and cystic spina bifida, neurological signs are immediately observed after birth; while in occult spina bifida the clinical signs are often not observed (REZAZADEH \& DEZFOULI, 2008). Open spina bifida is characterized by protrusion of the meninges and spinal cord exposure due to lack of skin coverage, while in cystic spina bifida the protrusion is into the subarachnoid space. Both may cause displacement of nerve roots, leading to neurological signs (CANTILE \& YOUSSEF, 2016) which vary according to the affected region (i.e., difficulty standing, fecal and urinary incontinence, paraparesis of pelvic limbs) with no signs of brain involvement (GÓRRIZ- 
MARTÍN et al., 2019; STEELE et al., 2019). The present study aimed to describe the clinical and pathological aspects of open spina bifida and diplomyelia along with other central nervous system malformations in a Texel lamb, as well as to discuss the pathogenesis of these conditions in this lamb. To the authors' knowledge, this is the first case report of open spina bifida in a lamb in Rio Grande do Sul State, Brazil.
A seven-day-old, male Texel lamb had a history of paresis of the thoracic limbs, paralysis of the pelvic limbs and dysuria, with urine release only through bladder compression since birth. The animal was alert, with suckling reflexes, regular body condition, and with moderate atrophy of the pelvic limb skeletal muscles. In the lumbar region, a dorsal skin defect measuring $7 \times 2 \mathrm{~cm}$ was observed (Figure 1A). Due to the poor prognosis, the lamb was

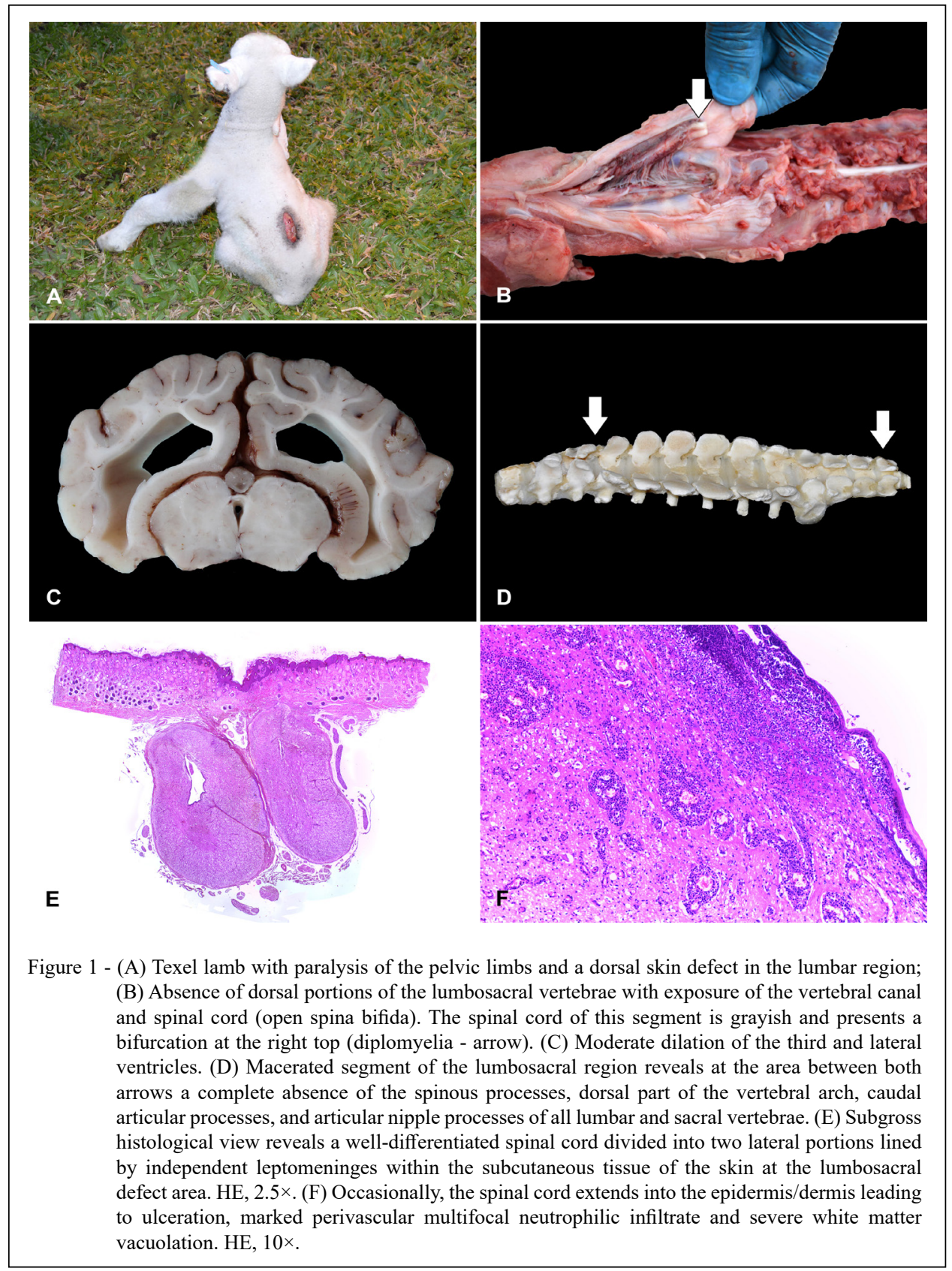

Ciência Rural, v.51, n.12, 2021. 
euthanized. The lamb was born in a property located in Encruzilhada do Sul, Rio Grande do Sul State, with an area of 174.81 hectares and a herd composed of 320 adult female sheep for the purpose of producing lambs for meat production. These females were raised extensively on ryegrass pastures (Lolium multiflorum) and improved native pasture. In the lambing period of the year of birth of the lamb here reported (2018), the property had an abortion rate of $5.1 \%$, but no abnormal alterations were observed in the fetuses. Moreover, there was no history of detection of congenital malformations in the property, and toxic plants able to cause such lesions, as Conium maculatum or Mimosa tenuiflora, were not observed in the property.

At necropsy, there was a focally extensive disruption of the skin in the lumbosacral region associated with absence of the dorsal portions of the $1^{\text {st }}$ to $6^{\text {th }}$ lumbar vertebrae and sacral vertebrae, with exposure of the vertebral canal and spinal cord (open spina bifida). The spinal cord of this segment was grayish and soft near to the lumbar failure, and within this area the spinal cord had two lateral portions outlined by different meninges (diplomyelia; Figure 1B). Moreover, there was mild cerebellar coning and the brain was moderately swollen with flattening of the sulci and narrowing of the gyri, which were caused by moderate communicating hydrocephalus involving the mesencephalic aqueduct, third and lateral ventricles (Figure 1C). The urinary bladder, both ureters, and renal pelvis were markedly distended by urine (hydroureter and hydronephrosis). Samples representative of all organs were collected, routinely processed for histology and stained with hematoxylin and eosin (HE). The vertebral segment of the lumbosacral region with bone malformation was macerated, boiled in water and cleared by immersion in $10 \%$ hydrogen peroxide. With this analysis, a complete absence of the spinous and dorsal processes of the lumbosacral vertebrae was observed (Figure 1D).

Microscopically, the malformed segment of the vertebrae contained a well-differentiated spinal cord divided into two lateral portions which were outlined by independent leptomeninges (diplomyelia). This tissue was mostly contained within the subcutaneous tissue, but often extended into a diffusely ulcerated epidermis (Figure 1E). In addition, severe hyperemia, marked perivascular multifocal neutrophilic infiltrate, moderate white matter vacuolation intermixed by axonal spheroids, as well as countless necrotic neurons within the grey matter were noted in the spinal cord (Figure 1F). The ependymal canal of these segments was moderately dilated and filled with fibrin. The ulcerated epidermis was covered by large amounts of fibrin and degenerated neutrophils, as well as it presented multifocal areas of neovascularization at the vicinities of the nervous tissue. The thoracic spinal cord exhibited moderate hydromyelia and a focal area of vacuolation of the grey matter, with rare axonal spheroids. The other organs were unremarkable.

Serum samples were submitted to RT-PCR in order to detect Pestivirus (bovine viral diarrhea virus [BVDV]), Schmallemberg virus (SV), and Bluetongue virus (BTV), according to previously described methodologies (HOFFMANN et al., 2009; BILK et al., 2012; WEBER et al., 2014), but all yielded negative results.

The diagnosis in the present case of spina bifida and diplomyelia associated with multiple malformations in a Texel lamb was based on the clinical and pathological findings. Clinically, it presented neurological signs of compression and displacement of lumbosacral nerve roots responsible for the sensory and motor innervation of the pelvic limbs, bladder, and anus (DE LAHUNTA \& GLASS, 2009; CANTILE \& YOUSSEF, 2016). In addition, microscopic lesions of severe infiltrate, necrosis and vacuolation were compatible with the clinical signs. Clinical signs of dysuria and urinary incontinence can be explained by a lesion in the medullary region responsible for emptying the bladder, affecting the pudendal nerve and the innervation of the detrusor muscle and urethral muscles, inhibiting their contraction (DE LAHUNTA \& GLASS, 2009). At necropsy, hydronephrosis, hydroureter, and marked bladder distention were observed, possibly due to a prolonged inability to urinate.

Hydromyelia in the thoracic and lumbar segments of the spinal cord is an unusual change in domestic animals, but often associated with cases of spina bifida (POTTER et al., 2010; HUT et al., 2017; GÓRRIZ-MARTÍN et al., 2019). The compression of the lumbar region of the spinal cord most likely prevented the cerebrospinal fluid (CSF) flow into the ependymal canal, generating hydromyelia at the proximal segments of the spinal cord. Additionally, a reduced resorption of the CSF at the subarachnoid spaces, which characterizes a communicating hydrocephalus, probably increased the pressure within the ventricular system, resulting in dilation of the mesencephalic aqueduct, third and lateral ventricles, as well as promoting cerebellar coning (DE LAHUNTA \& GLASS, 2009). However, there were no clinical signs related to these changes. 
At necropsy, there was complete absence of the spinous processes, dorsal part of the vertebral arch, caudal articular processes and articular nipple process, similarly to that described in other studies (POTTER et al., 2010; GUTZWILLER et al., 2014; STEELE et al., 2019). The cause of these malformations, as in the present case, is unknown, with sporadic case reports (GUTZWILLER et al., 2014). Nonetheless, a genetic component has been indicated in investigations with calves and lambs, suggesting a possible inherited recessive anomaly, with an influence of a dominant gene with low penetrance and variable expressiveness (GÓRRIZ-MARTÍN et al., 2019; STEELE et al., 2019).

Possible etiologies considered in this case were Pestivirus (BVDV), Orbivirus (BTV), and SV. The first is associated with birth defects, abortions, and stillbirths predominantly in cattle (CANTILE \& YOUSSEF, 2016), while infection in sheep is associated with stillbirths and neonatal death (SCHLAFER \& FOSTER, 2016), which are distinct from the present case. SV infection may cause vertebral malformations in sheep, but these are predominantly characterized by changes in position, torticollis, scoliosis, kyphosis, and/or lordosis (PEPPERKAMP et al., 2015; SCHLAFER \& FOSTER, 2016). Moreover, changes in the central nervous system related to SV and BTV infections result mostly from tissue loss with microencephaly, hydranencephaly, and anencephaly, as well as dysplasia within the cerebellum, medulla oblongata, and spinal cord (PEPPERKAMP et al., 2015), differing from the present report, in which duplication of the spinal cord was evidenced (diplomyelia). Poisoning by plants with toxic teratogenic principles that may cause congenital anomalies in the nervous and musculoskeletal systems (RIETCORREA et al., 2012) were other possible causes considered in the present case. Mimosa tenuiflora and M. ophthalmocentra, widely found in Brazil, are examples of these causes (DANTAS et al., 2010; RIET-CORREA et al., 2012), but none of these were observed on the property.

This research highlighted the clinical presentation and the associated pathological findings of spina bifida in a lamb. Possible viral or toxic etiologies have not been identified and, therefore, a possible genetic cause could be considered.

\section{ACKNOWLEDGEMENTS}

This research was supported by Conselho Nacional de Desenvolvimento Científico e Tecnológico $(\mathrm{CNPq})$ and it was financed in part by Coordenação de Aperfeiçoamento de Pessoal de Nível Superior (CAPES). Brazil - Finance code 001. We are also thankful to the owner of the property André Camozzato.

\section{DECLARATION OF CONFLICT OF INTEREST}

The authors declare no conflict of interest. The founding sponsors had no role in the design of the study; in the collection, analyses, or interpretation of data; in the writing of the manuscript, and in the decision to publish the results.

\section{AUTHORS' CONTRIBUTIONS}

All authors contributed equally for the conception and writing of the manuscript. All authors critically revised the manuscript and approved of the final version.

\section{BIOETHICS AND BIOSSECURITY COMMITTEE APPROVAL}

We authors of the article entitled "Spina bifida, diplomyelia and multiple malformations in a Texel lamb" declared for all due purposes that the project that gave rise to the present data of the same has not been submitted for evaluation of the Ethics Committee of the Universidade Federal do Rio Grande do Sul (UFRGS), but we are aware of the content of the Brazilian resolutions of the Conselho Nacional de Controle de Experimentação Animal (CONCEA) if it involves animals. Thus, the authors assumed full responsibility for the presented data and are available for possible questions, should they be required by the competent authorities.

\section{REFERENCES}

BILK, S., et al. Organ distribution of Schmallenberg virus RNA in malformed newborns. Veterinary Microbiology, v.159, n.12, p.236-238, 2012. Available from: <http://doi.org/10.1016/j. vetmic.2012.03.035>. Accessed: Feb. 10, 2020. doi: 10.1016/j. vetmic.2012.03.035.

CANTILE, C.; YOUSSEF, S. Nervous system. In: MAXIE, M. G. Jubb, Kennedy \& Palmer's Pathology of Domestic Animals. St Louis: Elsevier, 2016. Vol. 1(4), p. 250-406.

DANTAS, A. F. M., et al. Malformações congênitas em ruminantes no semiárido do Nordeste Brasileiro. Pesquisa Veterinária Brasileira, v.30, n.10, p.807-815, 2010.

DE LAHUNTA, A.; GLASS, E. Veterinary Neuroanatomy and Clinical Neurology. St. Louis: Elsevier Saunders, 2009.

GÓRRIZ-MARTÍN, L. et al. Split spinal cord malformations in 4 Holstein Friesian calves. BMC Veterinary Research, v.15, n.1, p.307, 2019. Available from: <https://doi.org/10.1186/s12917019-2055-x>. Accessed: Feb. 10, 2020. doi: 10.1186/s12917019-2055-X

GUTZWILLER, N. et al. Spina bifida aperta in a sheep lamb. Schweizer Archiv Für Tierheilkunde, v.157, n.1, p.49-54, 2014. Available from: <https://doi.org/10.17236/sat00004>. Accessed: Nov. 03, 2019. doi: 10.17236/sat00004. 
HOFFMANN, B. et al. Real-time quantitative reverse transcriptionPCR assays specifically detecting Bluetongue Virus serotypes 1, 6, and 8. Journal Of Clinical Microbiology, v.47, n.9, p.2992-2994, 2009. Available from: <https://doi.org/10.1128/jcm.00599-09>. Accessed: Feb. 10, 2020. doi: 10.1128/jcm.00599-09.

HUT, P. et al. Congenital diplomyelia and hydromyelia in two calves. Veterinary Record Case Reports, v.5, n.3, p.1-5, 2017. Available from: <https://doi.org/10.1136/ vetreccr-2017-000489>. Accessed: Nov. 15, 2019. doi: 10.1136/ vetreccr-2017-000489.

PEPPERKAMP, N. H. et al. (2015). Ovine and bovine congenital abnormalities associated with intrauterine infection with Schmallenberg Virus. Veterinary Pathology, v.52, n.6, p.1057-1066, 2015. Available from: <https://doi. org/10.1177/0300985814560231>. Accessed: Feb. 10, 2020. doi: $10.1177 / 0300985814560231$

POTTER, K. A., et al. Spina bifida with associated malformations of the central nervous system in Dorper-cross sheep. New Zealand Veterinary Journal, v.58, n.6, p.315-318, 2010. Available from: $<$ https://doi.org/10.1080/00480169.2010.69763>. Accessed: Nov. 03, 2019. doi: 10.1080/00480169.2010.69763.
REZAZADEH, F.; DEZFOULI, M. Congenital abnormalities in two Holstein calves with spina bifida occulta, tail absence, achondroplasia and brachygnathia inferior: a case report. Journal of Animal and Veterinary Advances, v.7, n.4, p.475-477, 2008.

RIET-CORREA, F. et. al. A review of poisonous plants that cause reproductive failure and malformations in the ruminants of Brazil. Journal of Applied Toxicology, v.32, p.245-254, 2012. Available from: <https://doi.org/10.1002/jat.1754>. Accessed: Apr. 09, 2021. doi: $10.1002 /$ jat. 1754 .

SCHLAFER, D. H.; FOSTER, R. A. Female genital system. In: MAXIE, M. G. Jubb, Kennedy \& Palmer's Pathology of Domestic Animals. St Louis: Elsevier, 2016. v.1(5), p.358-464.

STEELE, J. W. et al. Heritable spina bifida in sheep: a potential model for fetal repair of myelomeningocele. Journal Of Pediatric Surgery, v.55, n.3, p.475-481, 2019. Available from: <https://doi. org/10.1016/j.jpedsurg.2019.06.019>. Accessed: Feb. 1, 2020. doi: 10.1016/j.jpedsurg.2019.06.019.

WEBER, M. N. et al. High frequency of bovine viral diarrhea virus type 2 in Southern Brazil. Virus Research, v.191, p.117-124, 2014. Available from: <https://doi.org/10.1016/j.virusres.2014.07.035>. Accessed: Feb. 01, 2020. doi: 10.1016/j.virusres.2014.07.035. 